\title{
DETERMINING THE AGE OF STREETSIDE TILIA CORDATA TREES WITH A DBH-BASED MODEL
}

\author{
By Jan Lukaszkiewicz' ${ }^{1}$ Marek Kosmala², Magdalena Chrapka ${ }^{3}$, and J acek \\ Borowski ${ }^{4}$
}

\begin{abstract}
This paper evaluates the possibility of determining tree age based on diameter at breast height (dbh, taken at $1.3 \mathrm{~m} \mathrm{[4.3}$ $\mathrm{ft}]$ ), using common lime (linden, Tilia cordata). We first identified and measured groups of trees growing in similar conditions (alleys and roadside trees) whose age was known. We developed a regression model describing the growth of trees over time. Plotting tree age against diameter yielded a correlation coefficient $r=0.962$ and determination coefficient $r^{2}=0.926$. The resulting model was applied to unrelated groups of trees of known age. The difference between the actual age and mean age calculated with the model was less than $10 \%$. The model was then compared to measurements taken with a Resistograph, with results being highly concordant. The model, although not meant for application to individual trees, might be useful in determining the age of common lime trees growing in alleys and along roads.

Key Words. Common lime; dbh; linden; roadside trees; Tilia cordata; tree age.
\end{abstract}

In arboriculture and urban forestry, determination of the age of trees is helpful in

- setting the chronology of parks and gardens,

- determining the age structure of tree stands for protection and conservation,

- forecasting and assessing threats associated with increasing age,

- forecasting the size of trees in the future.

Methods of determining tree age are not always effective. Most are invasive (such as the Pressler increment borer and the Resistograph) and damage the trunk (Weber and Mattheck 2005). The examination of wood structure (including the alignment of annual tree rings) of trees with a Resistograph is considered accurate (Isik and Li 2003). The Resistograph can be used to determine tree age, although the method is complex, expensive, and has its limitations, such as drilling tangential to the ring structure, decay within the trunk, and limited length of the boring bit. Moreover, invasive methods are time consuming and expensive.

The best-known noninvasive methods available are tree age tables, devised, among others, by Siewniak and Kusche (1994), Mitchell (1979), and Szczepanowska (2001). However, the determination of tree age using tables is often error prone. The main drawback seems to be insufficient correlation of tree age with the dbh and gaps in the age/dbh correlation. Log volume tables for forest trees fail to be reliable in urban environments. They are prepared for trees growing in forest stands of high density and cannot be applied to urban forests. The basic importance of density for tree development is emphasized by Henry and Aarssen (1999).

White (1998) presented a noninvasive method of age determination, combining elements of tree age tables with dendrochronological calculations. In addition, he related the size of trees to the type of site in which the trees were growing. This method, however, when tested on trees of known age and site conditions in central Poland, showed notable discrepancies. Moreover, it requires toilsome calculations.

Therefore, tree age tables, in spite of their numerous drawbacks, remain in use. Still lacking is an accurate method based on the relationship between tree size and age. Such a method should provide an acceptable margin of error and fast results. Such a method would facilitate the work of arborists.

The present work is aimed at determining the relationship between the variation in dbh of common lime trees (linden, Tilia cordata) growing as alley and streetside trees, and their real age, as found in historical documents. As a second stage, a verification of the obtained model is planned using another batch of trees with documented age in a reverse manner: their dbh measurements are converted to age with the aid of the model and then their real and calculated values compared. As a final stage, the results of two age determination methods will be compared: one obtained with the model and the other with the Resistograph, using another batch of trees.

\section{MATERIALS AND METHODS}

The initial stage of research consisted of finding potential areas for research, defined as single-species plantings of uniform age (Figure 1). This criterion was met by alley and street trees. We checked archives, including those of the National Centre for the Research and Documentation of Historic Monuments in Warsaw (Krajowy Osrodek Badan i Dokumentacji Zabytkow w Warszawie) in order to locate tree-lined alleys for which the year of planting was recorded. The search was limited to the region of Mazowsze (Mazovia), so that all the locations had uniform climatic conditions. The species selected for initial tests was common lime, a long-lived tree, often used to line alleys and streets in central Poland. 


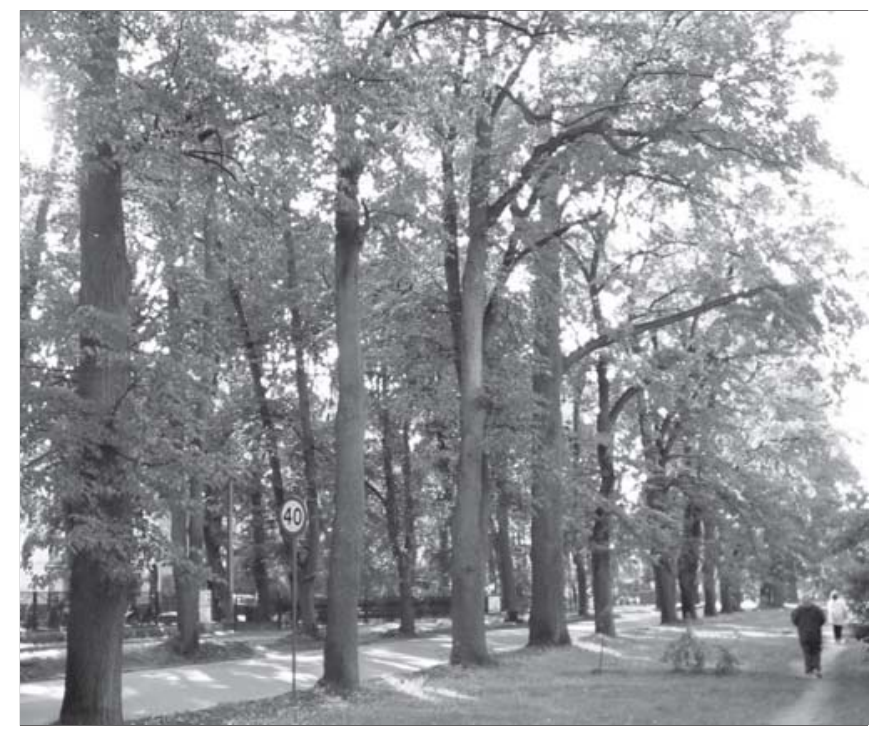

Figure 1. An alley of 95-year-old common lime (linden, Tilia cordata) trees in Komorow near Warsaw. This is an example of single-species plantings of uniform age taken into the model database. (Photo by Jan Lukaszkiewicz.)

The field measurements were made in Warsaw and in selected locations in the Mazowsze (Mazovia) region. They included dbh and circumference at $1.3 \mathrm{~m}$ (4.3 ft) height, and spacing between trees of representative age groups, made respectively with a calliper, altimeter, and measuring tape. The mean spacing between trees at all the sites was $6.22 \mathrm{~m}$ $(20.7 \mathrm{ft}) \pm 1.69 \mathrm{SD}$. Trees had no visible symptoms of internal wood decay (e.g., cavities) and no more than $20 \%$ crown dieback. The final inventory included 195 trees used to construct the database (Table 1). Two groups of trees were used to verify the model: 17 trees 34 years old, and 15 trees 85 years old. Their exact ages were obtained as in case of the model group (Table 2).

The age of the separate group of trees was determined with an IML E400 Resistograph with a $40 \mathrm{~cm}$ (16 in.) boring bit, 1 to $1.3 \mathrm{~m}$ ( 3.3 to $4.3 \mathrm{ft}$ ) above the ground. The trees were bored twice, from the northern and the eastern side of the trunk. The bore was set at a right angle to the trunk. The depth of the drilling was equal to half of the premeasured dbh, with a margin of 5 to $10 \mathrm{~cm}$ (2 to $4 \mathrm{in}$.), with the exception of trees with a diameter more than $70 \mathrm{~cm}$ (28 in.), where the depth of the drilled hole was limited by the length of the boring bit. The inventory included trees with a dbh ranging between 15 and $37 \mathrm{~cm}$ (6 and 14.8 in.).

\section{Data Analysis}

For all calculations, a STATISTICA 6.0 package was used, with a nonlinear estimation module (user regression) for preparing the model.

\section{RESULTS AND DISCUSSION \\ Preparation of the Age/Dbh Curve}

The model involved dbh values for 195 trees in 13 age groups (Table 1), whose exact age was found in relevant documents.

\section{Age of Trees Plotted Against Dbh}

Plotting tree age against diameter yielded the correlation coefficient $r=0.962$ and determination coefficient $r^{2}=0.926$. The exponential character of the model curve (Figure 2) reflects a gradual decrease in the dbh growth in proportion to the age of trees. The progressive reduction in annual tree rings in proportion to age has been generally observed as a phenomenon related to tree growth (Pigott 1989; White 1998; Larsen and Kristoffersen 2002). There is a considerable scatter of dbh values within a given age group.

\section{Verification of the Model}

To verify the model, 17 trees 34 years old and 15 trees 85 years old (one alley per one age group) (Table 2) were used. Their exact ages were known from the available documents. The calculated age of each tree was then obtained substituting its measured dbh value for $p$ in the model described in Figure 1. This level of variation (Figure 2) makes it impossible to use the model to read the age of an individual tree, but it should not preclude the possibility of assessing the average age of trees from a given site (Table 2). The estimated mean age is very close to the actual age. The difference between the average estimate and actual age did not exceed $10 \%$. The only drawback to this approach is the necessity of measuring of more than one tree.
Table 1. Common lime age groups incorporated in the model, dbh parameter included.

\begin{tabular}{|c|c|c|c|c|c|}
\hline Age group & Number of trees & $\begin{array}{l}\text { Known age* } \\
\text { (years) }\end{array}$ & $\frac{\text { Mean }}{(\mathrm{cm})}$ & $\frac{\mathrm{dbh}}{\text { (in.) }}$ & Standard deviation \\
\hline 1 & 10 & 7 & 3 & 1.2 & \pm 0.009 \\
\hline 2 & 8 & 18 & 17 & 6.8 & \pm 0.027 \\
\hline 3 & 17 & 25 & 21 & 8.4 & \pm 0.025 \\
\hline 4 & 40 & 34 & 27 & 10.8 & \pm 0.049 \\
\hline 5 & 10 & 36 & 31 & 12.4 & \pm 0.034 \\
\hline 6 & 2 & 43 & 25 & 10 & \pm 0.000 \\
\hline 7 & 1 & 45 & 29 & 11.6 & \pm 0.000 \\
\hline 8 & 20 & 53 & 38 & 15.2 & \pm 0.059 \\
\hline 9 & 23 & 58 & 48 & 19.2 & \pm 0.064 \\
\hline 10 & 4 & 63 & 46 & 18.4 & \pm 0.020 \\
\hline 11 & 15 & 85 & 61 & 24.4 & \pm 0.028 \\
\hline 12 & 25 & 95 & 72 & 28.8 & \pm 0.102 \\
\hline 13 & 14 & 110 & 83 & 33.2 & \pm 0.081 \\
\hline
\end{tabular}

*The real age of trees found in historical records. 


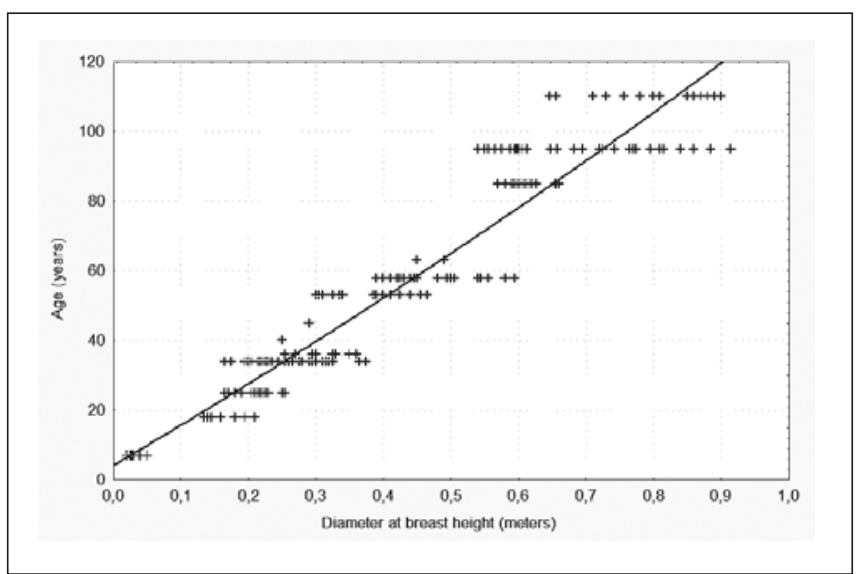

Figure 2. The best fit curve-a model-based age curve. Correlation coefficient $\boldsymbol{r}=\mathbf{0 . 9 6 2}$. Determination coefficient $\boldsymbol{r}^{2}=\mathbf{0 . 9 2 6}$. A regression equation was obtained: $y=-444.106+e^{\left(6.10556+(0.25433367)^{*} p\right)}$, where $y=$ age, $e=2.7183$, and $p=$ dbh.

Table 2. Results of the verification of the adopted model performed on groups of trees with known age, not involved in model development.

\begin{tabular}{llllll}
\hline $\begin{array}{l}\text { Age } \\
\text { group }\end{array}$ & $\begin{array}{l}\text { Number } \\
\text { of trees }\end{array}$ & $\begin{array}{l}\text { Known age } \\
\text { (years) }\end{array}$ & $\begin{array}{l}\text { Estimated } \\
\text { age (years) }\end{array}$ & $\begin{array}{l}\text { Mean } \\
\text { recovery }\end{array}$ & $\begin{array}{l}\text { SD* of } \\
\text { recovery }\end{array}$ \\
\hline 1 & 17 & 34 & 33.6 & $99.0 \%$ & \pm 11.9 \\
2 & 15 & 85 & 80.9 & $93.0 \%$ & \pm 7.2 \\
\hline
\end{tabular}

*Standard deviation.

Comparison of Age Readouts for Common Lime Trees, Estimated with the Model and with a Resistograph

Trace graphs obtained with the Resistograph were analyzed to identify annual tree rings. Tree age was determined based on the number of tree rings observed in a fragment with a known length $a$ by applying the following formula:

$$
W=P * S /(2 a)
$$

where $W=$ tree age, $P=$ dbh in centimeters, $S=$ the number of counted tree rings, and $a=$ the length of dbh fragment in which the tree rings were counted.

In instances when the boring holes were made both at north-south (NS) and east-west (EW), we calculated separately for $W_{\mathrm{NS}}$ and $W_{\mathrm{EW}}$, and then calculated $W$ as an average, applying the formula

$$
\mathrm{W}=\left(\mathrm{W}_{\mathrm{NS}}+\mathrm{W}_{\mathrm{EW}}\right) / 2
$$

The majority of results were integers. Each tree had its age determined with a Resistograph and then calculated using the model (Figure 3). The plot shows the regression line and the identity line. Note that tree age calculated with the model was an average 8 years or higher than the age calculated with the Resistograph.

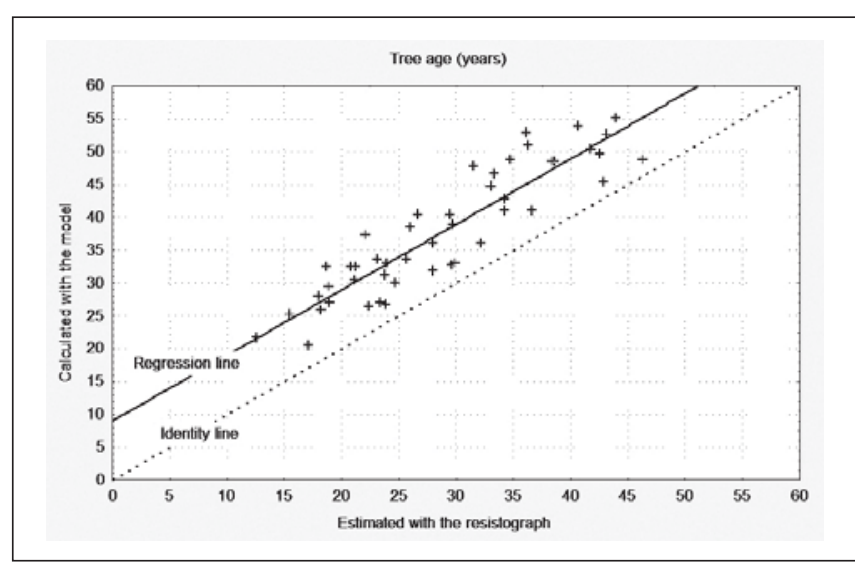

Figure 3. Estimated tree age recorded by the Resistograph versus calculated age.

\section{SUMMARY}

- A strong nonlinear correlation between dbh of trunks and the age of trees was observed in the age bracket under research.

- The verification of independent age groups (34 and 85 years old) demonstrated that the age of trees was determined with a precision of $1 \%$ and $7 \%$, respectively, for the average of age in a specific location.

- The exponent model showed considerable concordance with age measurements made with the Resistograph, although the model overestimates age by approximately 8 years.

\section{CONCLUSIONS}

- The model shows good accuracy in determining the average age of trees in low-density clusters, typical for alley and roadside tree populations.

- The method described can be used to determine the average age of tree groups but not individual trees.

- If used in this manner, the model is superior in that it is devoid of the systematic errors inherent in the Resistograph method.

- The observed differences between tree age determined with the model and the Resistograph may be partly accounted for by the boring of holes at a height of 1 to $1.3 \mathrm{~m}$ ( 3.3 to $4.3 \mathrm{ft}$ ). It takes trees a number of years to grow to this height, while the model accounts for the actual age of trees; therefore, age readouts obtained with the model are higher than those measured with a Resistograph.

- The described method of determining the age of trees, based on the above model, can be used in situations in which there is information about the origin of trees but the age remains unknown, while the invasive methods could be used in other cases, especially with single trees. To facilitate application of the exponent model in 
field conditions, it can be prepared in graphic form (Figure 4), where the $\mathrm{x}$ axis represents the mean dbh for alley or roadside trees, and the $y$ axis the age of the alley or roadside planting.

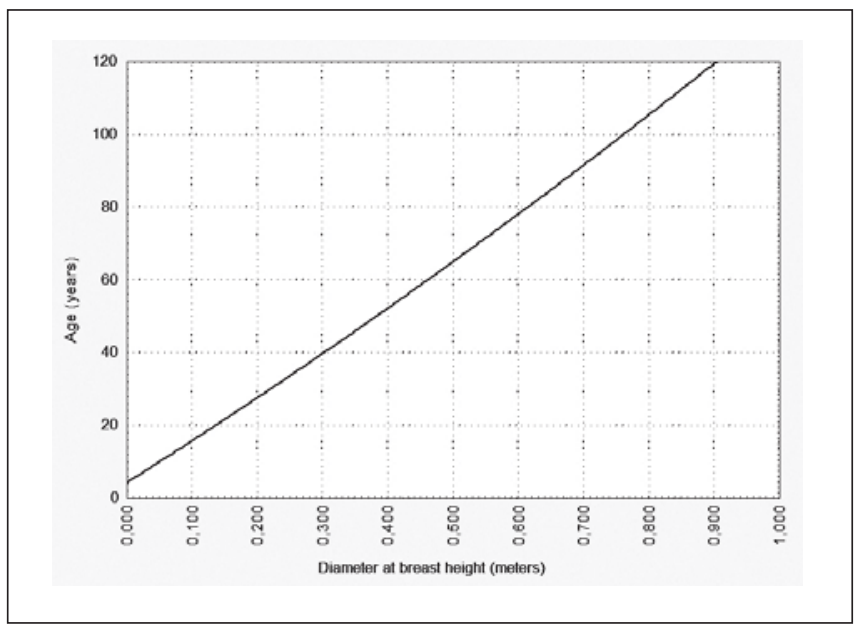

Figure 4. An example of the nomogram based on the model described in this paper, with a possible application for practical assessment of the average age of the roadside and alley plantings of common lime (linden, Tilia cordata) trees.

\section{LITERATURE CITED}

Henry, H.A.L., and Aarssen,W. 1999. The interpretation of stem diameter-height allometry in trees: Biomechanical constrains, neighbour effects, or biased regressions? Ecol. Lett. 2:89-97.

Isik, F., and Li, B. 2003. Rapid assessment of wood density of live trees using the Resistograph for selection in tree improvement programs. Can. J. For. Res. 33:2426-2435.

Larsen, F.K., and Kristoffersen, P. 2002. Tilia's physical dimensions over time. J. Arboric. 28(5):203-211.

Mitchell, A. 1979. A field guide to the trees of Britain and northern Europe. William Collins, Sons and Co., London, UK.

Pigott, C.D. 1989. Estimation of the age of lime-trees (Tilia spp.) in parklands from stem diameter and ring counts. Arboric. J. 13:289-302.

Siewniak, M., and Kusche, D. 1994. Baumpflege Heute. Patzer Verlag, Berlin-Hannover, Germany.

Szczepanowska, B. 2001. Drzewa w miecíse (Trees inside a city). Hortpress Sp. Z o.o., Warszawa, Poland.

Weber, K., and Mattheck, C. 2005. The Effects of Excessive Drilling on Wood Decay in Trees. Forschungszentrum Karlsruhe GmbH in der Helmholtz-Gemeinschaft. Institute for Materials Research. Karlsruhe, Germany.

White, J. 1998. Estimating the age of large and veteran trees in Britain. Forestry Practice. Forestry Commission, Edinburgh, UK.
${ }^{1}$ M.Sc., Postgraduate Student Department of Landscape Architecture Section of Landscape Construction and Maintenance Warsaw Agricultural University-SGGW Warszawa, Poland

${ }^{2 *}$ Associate Professor, Head of Section Department of Landscape Architecture Section of Landscape Construction and Maintenance Warsaw Agricultural University-SGGW ul. Nowoursynowska 159, bud. 37

02-776 Warszawa, Poland

kosmala@alpha.sggw.waw.pl

${ }^{3}$ M.Sc.

Department of Environmental Protection

Warsaw Agricultural University-SGGW

Warszawa, Poland

${ }^{4}$ Assistant Professor

Department of Environmental Protection

Warsaw Agricultural University-SGGW

Warszawa, Poland

*Corresponding author. 
Résumé. Cet article évalue la possibilité de déterminer l'âge des arbres en se basant saur le diamètre - au DHP à 1,3 m du sol - à partir du tilleul à petites feuilles (Tilia cordata). Nous avons d'abord identifié et mesuré des groupes d'arbres poussant dans des situations similaires (arbres le long d'allées et de rues) et dont l'âge était connu. Nous avons développé un modèle de régression décrivant la croissance des arbres dans le temps. En échantillonnant des arbres par rapport au diamètre, nous avons obtenu un coefficient de corrélation de $r=0,962$ et déterminé un coefficient de $r^{2}=0,926$. Le modèle obtenu a par la suite été appliqué à des groupes d'arbres sans lien entre eux et dont l'âge était inconnu. La différence entre l'âge actuel et l'âge moyen calculé avec le modèle était inférieure à $10 \%$. Le modèle a par la suite été comparé aux mesures prises par le résistographe, et ce avec des résultats qui ont été hautement concordants. Le modèle, même s'il n'a pas été mis au point pour des arbres individuels peut être utile pour déterminer l'âge de tilleuls poussant le long d'allées et de rues.

Zusammenfassung. Diese Studie bewertet die Möglichkeit, das Baumalter basierend auf dem Brusthöhendurchmesser am Beispiel Winterlinde zu messen. Zuerst identifizierten und maßen wir eine Gruppe von Bäumen mit gleichen Wachstumskonditionen (Strassen- und Alleebäume), deren Alter bekannt war. Wir entwickelten ein Regressionsmodell, welches das Wachstum der Bäume über die Zeit beschreibt. Das Plotten des Baumalters gegen den Durchmesser resultierte in einem Korrelationskoeffizient $r=0,962$ und einem Determinationskoeffizient $r^{2}=0,926$. Das resultierende Modell wurde auf eine nicht verbundene Gruppe von Bäumen mit bekanntem Alter übertragen. Der Unterschied zwischen dem aktuellen Alter und dem mittleren kalkulierten Alter war weniger als 10\%. Das Modell wurde dann mit Resistografmessungen verglichen, deren Ergebnisse ziemlich konform lagen. Dennoch war das Modell nicht für die Applikation bei individuellen Bäumen entwickelt, kann aber dafür nützlich sein, um das Alter von Strassen- und Alleebäumen zu bestimmen.

Resumen. Este reporte evalúa la posibilidad de determinar de las edad de los árboles con base en el diámetro (DBH - diámetro a $1.3 \mathrm{~m}(4.3 \mathrm{ft}$ )), usando el tilo común (Tilia cordata). Primero identificamos y medimos grupos de árboles creciendo en condiciones similares (árboles en camellón y de alineación) cuya edad era conocida. Desarrollamos un modelo de regresión describiendo el crecimiento de los árboles sobre el tiempo. El gráfico de la edad contra el diámetro del árbol dio un coeficiente de correlación $\mathrm{r}=$ 0.962 y un coeficiente de determinación $r^{2}=0.926$. El modelo resultante fue aplicado a grupos de árboles no relacionados de edad conocida. La diferencia entre la medida real y la edad media calculada con el modelo fue menor del 10\%. El modelo fue comparado entonces con mediciones tomadas con un resistógrafo, con resultados ampliamente concordantes. El modelo, con todo y que no es para árboles individuales, puede ser útil para determinar la edad de tilos comunes creciendo en camellones y a lo largo de las vías. 